The subcommittee staff counters that AT\&T last autumn said it could live with a provision in the Senate's version of this bill that required not only separate accounting, but an actual split of Bell Labs into regulated and unregulated divisions. Keefauver says that was only because the Senate bill would also have allowed AT\&T to hold onto its operating companies.

The Office of Technology Assessment (OTA), which was asked to testify at the House hearings on the bill, has suggested, however, that AT\&T's major objections to HR 5158 may not be directly related to Bell Labs. OTA staff point out that the antitrust settlement itself will have an enormous effect on Bell Labs' basic research mission, if for no other reason than by putting a premium on applied research as AT\&T enters the unregulated computer field. By comparison, OTA says, HR 5158 does relatively little.

The bill does, however, make some substantial changes in the anti-trust settlement's treatment of the Bell Operating Companies. It would in particular prevent AT\&T from taking over the very lucrative Yellow Pages, the operation of pay phones and the sale of terminal equipment from the operating companies. AT\&T would get all of these, along with a large share of the intrastate lines, under the settlement leaving the newly-independent operating companies with nothing but the right to "market a dial tone" as one critic put it.

The House Energy and Commerce Committee is expected to deal with HR 5158 quickly but the chances of its being passed are only fair.

Stephen Budiansky

\section{Spain for CERN}

Spain has rejoined the European Centre for Nuclear Research (CERN) in Geneva, but at a reduced price - less than a third of what it should pay on the CERN formula linking subscription to gross national product.

Starting next January, Spain will pay 2.1 per cent of the $£ 170$ million CERN budget (about $£ 3.5$ million), rising to its full 7.1 per cent only in 1989. The reduced subscription has been agreed because Spain as yet has too few highenergy physicists to make full use of membership. CERN will allocate the extra cash two ways: 40 per cent to reduce the contributions of other member states and 60 per cent to experiments.

Spain's benefits will be various. The move will help to prove Spain's interest in Europe when it is applying for membership of the European Economic Community. The few Spanish people already at work at CERN will now be able to apply for time on accelerators in their own right, and there may also be contracts to be won for the components of LEP, the large electron-positron collider that will be CERN's next accelerator.

\section{French research law \\ La loi at last}

La Loi is the law. Last week the French law for research and technology was finally adopted by the National Assembly in a form much like that originally proposed by the government, despite vehement Senate opposition which put it many weeks behind schedule. Now the race is on to promulgate the various consequent decrees which, for example, will redefine the role of organizations such as the Centre National de la Recherche Scientifique (CNRS).

While the research and industry ministry claims that the law adopted is "90-95 per cent" the same as the original, others point to "substantial" improvements in the protection afforded by the law to basic science. One amendment, for example, mentions the importance of fundamental research to the whole programme.

There is, however, no escaping the fact that the law is basically to do with technology, and with two objectives: to stimulate French effort in the new technologies and to "open up" French science to industry. The key provisions of the law are as follows:

- To raise the government budget for civil research and development by a real 17.8 per cent per year (on the average) to 1985 .

- To set up seven "programmes mobilisateurs" - tactical programmes (such as in biotechnology) on which the rest of the law (and funds) will be focused. The list of programmes may be modified each year, but for now will be: the rational use of energy and new energy sources; biotechnology; electronics; research and the Third World; improvement of working conditions; promotion of French as a scientific language; and a programme covering various industrial technologies.

- The creation of regional committees for research and development, consultative to the regional councils, which will have their own budgets and a degree of autonomy to develop a regional science policy.

- The creation of a new legal category of organization, "établissements publics à caractère scientifique et technologique", which will be applied to organizations such as CNRS. The formula will give these bodies an explicit duty to attempt to apply their work, to publicize their research and to train and educate researchers.

- A second category of organization "groupements d'intérèt public" - is created to allow bodies such as CNRS for a limited period to form profitable liaisons with industry.

- In a kind of inclusive job description, the "mission" of a researcher is defined as the development of knowledge, its transfer to industry and society, its popularization, the education and training of young and old and administration.

- All government researchers will become "fonctionnaires", giving them the envied security of civil servants which, hitherto, only university staffs have enjoyed.

Many in France consider these last two provisions as the most important. One outcome may be to increase the mobility of scientists between research and other jobs. Thus, say the hopeful, university careers may be unblocked while industry may be able to recruit more researchers.

Robert Walgate

\section{European research ministers Going where?}

\section{Brussels}

An unexpectedly lively debate between the EEC's research ministers took place last week when they met in Luxembourg to examine the flood of proposals from the European Commission. A distinctly positive response greeted the plans to change the structures of EEC research programmes and to launch the ambitious "Esprit", programme on information technology (see Nature 3 June, p.352). More detailed plans are to be prepared on both for the next research council in November this year.

The next stage will be to prepare detailed proposals by 1 January 1982 on the bulk of the Esprit programme, by which time the planned pilot projects should have established the credibility of the concept.

Discussion at the council meeting was also devoted to the Super Sara project at the EEC's Joint Research Centre at Ispra in Italy which will carry out research on nuclear safety. There was some grumbling that it is likely to cost more than at first estimated, but no definite decision was made on this or the ideas put forward for all the joint research centres.

A squabble did develop over the 1982-86 research programme on medicine and public health, for which the Commission had proposed a budget of 20 million units of account ( $£ 36$ million). Most countries preferred 16.9 million units of account, while the British and West Germans argued in favour of even less, 10 million units. Before there is official agreement, however, the European Parliament will have to be consulted.

Commission officials will be heartened by the seriousness with which the member states are now taking the urgency of starting large-scale cooperation not only on information technologies but in other sectors too. A fully-fledged framework programme on the stimulation of the Community's scientific and technological potential in the 1980 s will be ready in November. "A new leaf has been turned in the history of the Community's research strategy. The fragmentary approach which characterized joint Community research and development in the past has been left behind and we are now moving towards objectives which reflect the EEC's real priorities", Vicomte Etienne Davignon was reported to have told the ten ministers in Luxembourg.

Jasper Becker 